\title{
Assessment of acute and subchronic oral toxicity of ethanolic extract of Pothomorphe umbellata L. Miq (Pariparoba)
}

\author{
Sonia Barros' ${ }^{1}$, Cristina Dislich Ropke', Tânia Cristina Higashi Sawada', Vanessa Vitoriano da Silva', \\ Sônia Maria Miranda Pereira ${ }^{2}$ e Silvia Berlanga de Moraes Barros ${ }^{1 *}$
}

${ }^{1}$ Departamento de Análises Clínicas e Toxicológicas, Faculdade de Ciências Farmacêuticas, Universidade de São Paulo, ${ }^{2}$ Setor Citologia Oncótica, Divisão de Patologia, Instituto Adolfo Lutz

*Correspondence:

Silvia Berlanga de Moraes Barros

Departamento de Análises Clínicas e

Toxicológicas

FCF-USP

Av. Prof. Lineu Prestes, 580, Bloco 17 05508-900 - São Paulo - SP - Brasil

E-mail:smbarros@usp.br
There is a high degree of concern regarding the secure use of plant extracts and, for this very reason, preclinical and clinic toxicological evaluation of these extracts are needed. With the aim to assure the quality and the safety of the extract and due to the scarcity of literature information about Pariparoba extract toxicity, our purpose was to investigate the acute and subchronic toxicity of the standardized ethanolic dried root extract of Pothomorphe umbellata L. Miq. This extract was administered orally to adult swiss mice and wistar rats and the mutagenic potencial of the extract was also evaluated. The extract showed to be non toxic.

\section{INTRODUCTION}

Pothomorphe umbellata L. Miq. (Piperaceae), known in Brazil as Pariparoba or Capeba, grows in the states of São Paulo, Minas Gerais, Espírito Santo and Bahia (Kijjoa et al., 1980; Van den Berg, 1993; Panizza, 1997). Roots and leaves are widely used for the treatment of liver diseases and inflammatory disorders in tropical South America (Kijjoa et al., 1980; Barros et al, 1996). For this reason the roots of Pothomorphe umbellata L. Miq. were included in the first edition of the Brazilian Pharmacopoeia (Silva, 1929). The members of the Piperaceae family are rich in substances such as phenols, phenolic esters, terpenoids and ethers (Gibbs, 1974; Calle, 1983). Kijjoa et al., (1980), isolated from Pothomorphe umbellata L. Miq. a phenolic compound, 4nerolidylcatechol, with high antioxidant activity in vitro (Barros et al., 1996). There is a high degree of concern regarding the safety use of plant extracts. With the aim to ensure the quality and safety of phytomedicines, the National Agency of Sanitary Surveillance of Brasil (ANVISA) published on February 24, 2000, the Resolution $\mathrm{n}^{\circ} 17$ (Brazil, 2000) establishing that phytomedicines should be submitted to pre-clinical and clinical toxicological and pharmacological assays. As no information exists in the scientific literature about pariparoba extract toxicity, our purpose was to investigate the oral acute and subchronic toxicity of the standardized ethanolic dried root extract of Pothomorphe umbellata L. Miq. to laboratory animals.

\section{MATERIAL AND METHODS}

\section{Plant material and extract preparation}

The roots of Pothomorphe umbellata L. Miq. were collected in the "Armando de Salles Oliveira" campus of the University of São Paulo, at São Paulo city (South-east of Brazil). An herbarium specimen is deposited in the De- 
partamento de Botânica, Instituto de Biociências, Universidade de São Paulo (Sonia and Cris n ${ }^{\circ} 01$ ). Ethanol:water (1:1) extract was prepared from dried powdered roots. Plant material was percolated with ethanol:water 1:1 according to the Brazilian Pharmacopoeia (Silva, 1929), and then dried by lyophilization. This extract was referred as crude extract and employed for the toxicological assays.

\section{Standardization of the extract}

4-nerolidylcatechol (4-NC) was employed as a marker for the extract standardization. The concentration of 4-NC was determined in the crude extract of Pothomorphe umbellata L. Miq. by high performance liquid chromatography. The chromatographic system consisted of a Consta Metric 3200 bomb, coupled with a UV spectrophotometer detector (Waters model 481), settled at wavelength of $282 \mathrm{~nm}$. A Phenomenex PP18 $5 \mu(4.6 \times 250 \mathrm{~mm})$ column was used with a mobile phase of methanol:water 9:1 with a flux of $0,8 \mathrm{~mL} / \mathrm{min}$. Pure $4-\mathrm{NC}$, kindly provided by Professor Massuo Jorge Kato, Instituto de Química, Universidade de São Paulo, was used as standard. The dried crude extract employed in this study contained $6,5 \%$ of 4 -nerolidylcatechol.

\section{Animals}

Adult Swiss mice ( $32 \pm 7,5 \mathrm{~g}$ body weight) and Wistar rats $(200 \pm 30 \mathrm{~g}$ body weight $)$ were used for the assessment of the acute toxicity. Animals of both sexes (females nulliparous and no pregnant) were randomly assigned to control and treated groups ( 5 animals per group/ cage). For the subchronic study male and female (nulliparous and no pregnant) adult Wistar rats were employed. Animals were randomly assigned to control and treated groups (10 males and 10 females per group). Animals received food (Labina ${ }^{\circledR}$-Purina) and water $a d$ libitum (Brito, 1994).

\section{Acute toxicity evaluation}

Mice and rats received by gavage 1,2 or $5 \mathrm{~g} / \mathrm{k}$ of body weight (Limit test) of an aqueous suspension of dried root ethanolic extract of Pothomorphe umbellata L. Miq (United States, 1992; Brito, 1994; Brasil, 1996). Control group received isovolumetric amounts of water. Mice and rats were observed thoroughly during the first 24 hours for the onset of any immediate toxic signs and daily during the 13 days observation period to record any delayed acute effects. All animals were killed after 14 days according to the Ethical Principles of Animal Experimentation proposed by the COBEA (Colégio Brasileiro de Experimentação Animal, 2003).

\section{Subchronic toxicity evaluation}

Rats were dosed by gavage ( $500 \mathrm{mg} / \mathrm{kg}$ body weight) for a period of 40 days ( 5 days per week) with an aqueous suspensions of the ethanolic crude extract of Pothomorphe umbellata L. Miq (United States, 1992; Vaittinen et al., 1995; Krysiak et al., 1996). Food and water consumption and body weight were measured three days per week. During the experimental period all animals were observed thoroughly for the onset of any signs of toxicity. At the end of the experiment, the animals were killed under light ether anesthesia according to the Ethical Principles of Animal Experimentation proposed by the COBEA (Colégio Brasileiro de Experimentação Animal , 2003) and selected organs (liver, kidney, spleen and heart), after macroscopic observation, were excised and processed for routine microscopic examination. Blood samples were collected for hematological and biochemical analysis.

\section{Histopathological studies}

Slices of liver, kidney, spleen and heart were fixed in formaldehyde $5 \%$, embedded in paraffin wax, sectioned at $5 \mu$ and stained with haematoxylin and eosin (Pearse, 1968). Detailed microscopic examination was carried out in those organs of both control and treatment groups of both sexes.

\section{Hematological analysis}

Blood samples were collected under 10\% EDTA/ saline pH 7.2 and examined for hemoglobin concentration, packed cell volume, total erythrocyte count, and total and differential leukocytes counts (Kjeldsberg, 1998; Moura, 1982; Smith, 1995).

\section{Biochemical analysis of serum}

Whole blood samples were collected and allowed to clot. After centrifugation the serum was analyzed for cholesterol, triglycerides, glucose, alanine aminotransferase (ALT) and aspartate aminotransferase (AST) employing standard kits (SERA-PAK ${ }^{\circledR}$ Cholesterol Fast Color - Bayer, SERA-PAK ${ }^{\circledR}$ Triglycerides Fast Color - Bayer, SERA-PAK ${ }^{\circledR}$ Glucose Fast Color - Bayer, IFCC - Roche and IFCC - Roche, respectively). Serum samples were also analyzed for creatinine (Larsen, 1972), total protein (Gornall et al., 1949) and urea (Henry, 1991). 


\section{In vivo mutagenic potential}

Considering that root extracts of Pothomorphe umbellata L. Miq are rich in 4-nerolydilcatechol, a phenolic derivative, and due to the potential mutagenic properties of this class of compounds, the mutagenic assessment of the extract was evaluated (MadrigalBujaidar et al., 1998; Wong \& McLean, 1999).

The in vivo bone marrow micronucleus test was the assay of choice. It is a mammalian in vivo test, which detects damage to the chromosomes or to the mitotic apparatus by chemicals (United States, 1992). The micronucleus test is used to identify mutagenic compounds, that is, those that are capable of inducing structural changes in chromosomes (WHO, 1985)

The test is based on the increase in the frequency of micronucleated polychromatic erythrocytes in bone marrow of treated animals (United States, 1992). In the micronucleus test, mutagenic effects can be measured indirectly by counting small nuclei (one or several for cell) in interphase cells. These nuclei are formed from acentric chromosome fragments or whole chromosomes, which lag behind anaphase of cell division (WHO, 1985; United States, 1992; Rabello-Gay, 1991). Micronucleus test is, usually, carried out in mice. Animals are treated and polychromatic erythrocytes of bone marrow are stained and examined (Hodgson, 1997).

Adult male Swiss mice (35 g mean body weight) were acclimatized during three days before the start of the study receiving food (Labina ${ }^{\circledR}$-Purina) and water $a d$ libitum (Walker, 1984). The animals were randomly distributed in 5 groups ( 5 animals each). The first group, negative control, received isovolumetric amounts of distillated water. The second group, positive control, received $50 \mathrm{mg} / \mathrm{Kg}$ of the cyclophosphamide (Ribeiro et al., 1993). Treated groups received 1, 2 or $5 \mathrm{~g} / \mathrm{Kg}$ (Limit test) of an aqueous suspension of dried root ethanolic extract of Pothomorphe umbellata L. Each animal was dosed twice in and interval of 24 hours.

The animals were killed by cervical dislocation $24 \mathrm{~h}$ after the last treatment. Both femurs were removed, washed, and the epiphyses were cut to expose the medullary channel. Bone marrow was aspirated and suspended several times until its spread through serum as a fine suspension. The material was centrifuged at 2,000 rpm for 5 minutes. The supernatant was removed, the sediment carefully aspirated with pipette, and one drop placed on a clean slide. A fine smear was obtained with the aid of a coverslip. The slides were stained with Wright and Giemsa (Rabello-Gay, 1991) and analyzed under light microscopy with a 100x immersion objective. The number of micronucleated cells was counted in 1,000 per animal (Rabello-Gay, 1991). The rate of monochromatic erythrocytes to polychromatic erythrocytes was determinate in the same sample to describe the cytotoxic effect (Mengs et al., 1997).

\section{Statistical analysis}

Body weight, water and food intake, biochemical and hematological determinations were analyzed by the Student "t" and Mann-Whitney tests. For the micronucleus analysis the Fisher test was employed to detect statistical differences between control and treated groups (Pereira, 1991). All comparison tests were two-tailed, and a probability level of Pd"0.05 was considered significant.

\section{RESULTS}

\section{Acute toxicity evaluation}

Mice and rats administered Pothomorphe umbellata L. Miq. root extract did not develop any clinical signs of toxicity either immediately or during the posttreatment period with 1,2 and $5 \mathrm{~g} / \mathrm{kg}$. No mortality occurred in both species either immediately or during the 14-day observation period. $5 \mathrm{~g} / \mathrm{kg}$ body weight dose was considered as the "Limit test" as recommend by the acute toxicity testing procedures. Administration of further higher doses was considered physiologically unsound and, is not generally recommended.

Oral administered Pothomorphe umbellata L. Miq. root extract did not cause any appreciable alterations in water and food intake (data not shown) during 2 weeks in both species. Further, body weight gain during the observation period among the treated animals was comparable to their respective controls. No sex-related differences were evident in either species.

\section{Subchronic toxicity in rats}

Administration of Pothomorphe umbellata L. Miq. root extract for 40 days produced no signs of toxicity or mortality during the experimental period, in both sexes. The treated animals did not show any significant alteration in water or food consumption, nor in body weight during the experimental period. Furthermore, the animals showed no symptoms of diarrhea, piloerection, convulsion, and sleepiness.

Hematological parameters in the Pothomorphe umbellata L. Miq. root extract-treated rats were not markedly changed (Table I). 
Serum clinical chemistry showed only a few consistent changes. Among the serum biochemical parameters tryglycerides were increased by $39 \%$ in treated male rats and AST activity was $24 \%$ decreased in females. Serum protein content decreased in both sexes (Table II).

Macro and microscopic observations indicated no alteration in liver, spleen, kidneys and heart of the treated animals with $500 \mathrm{mg} / \mathrm{kg}$ of Pothomorphe umbellata L. Miq. root extract.

In the mutagenic assessment of Pothomorphe umbellata L. Miq. root extract, treated animals showed a statistically low frequency of micronuclei in relation to the positive group (Table III) .

This frequency was very near of the spontaneous rate of polychromatic erythrocytes (PCEs) with micronucleus, which consist about 3 micronuclei per 1000 PCEs (Rabello-Gay, 1991). Data indicated that the extract does not present a mutagenic activity as reflect by the mouse bone marrow micronucleus test.

\section{DISCUSSION}

The toxicological evaluation of a plant extract seeks to determine its possible collateral effects, to ensure the safety of use.

Some factors are capable to interfere in the toxicity of medicinal plants extract. This toxicity can be intrinsic of the vegetable drug or it happens during the process of extract preparation (Bacchi, 1996). The toxicity of the drug is related to its compound(s), and could be attributed to the active principle or not.

With the aim to guarantee the quality and safety of phytomedicines, the National Agency of Sanitary Surveillance (ANVISA) published in 2000 the Resolution - RDC ${ }^{\circ} 17$, (Brazil, 2000), establishing that phytomedicines should present scientific studies that check for the safety use of the medicine by pre-clinic and clinical toxicology. It is, however, the Directive $n^{\circ} 116 / 96$ of the Secretary-ship of Sanitary Surveillance of the Ministry of the Health (Brazil, 1996), that establishes the

TABLE I - Hematological parameters of rats treated or not with $500 \mathrm{mg} / \mathrm{kg}$ body wieght of Pothomorphe umbellata crude dried ethanolic extract by gavage during 40 days, 5 days per week

\begin{tabular}{lcccc}
\hline Group & $\begin{array}{c}\text { Leukocytes } \\
\left(\mathbf{c e l l s} / \mathbf{m m}^{3}\right)\end{array}$ & $\begin{array}{c}\text { Erythrocytes } \\
\left(\mathbf{c e l l s \times 1 0} / \mathbf{m m}^{3}\right)\end{array}$ & $\begin{array}{c}\text { Hemoglobin } \\
(\mathbf{g} / \mathbf{d l})\end{array}$ & $\begin{array}{c}\text { Packed cell volume } \\
(\mathbf{m g} / \mathbf{d l})\end{array}$ \\
\hline Male & & & & \\
Control & $2570 \pm 708$ & $8,275 \times 10^{6} \pm 0,795$ & $17,27 \pm 0,764$ & $45,67 \pm 3,336$ \\
Treated & $3350 \pm 1444$ & $8,226 \times 10^{6} \pm 0,299$ & $16,93 \pm 0,968$ & $45,60 \pm 1,897$ \\
& & & & \\
Female & & & & \\
Control & $2020 \pm 449$ & $7,01 \times 10^{6} \pm 1,16$ & $14,75 \pm 1,790$ & $39,10 \pm 5,173$ \\
Treated & $2340 \pm 688$ & $7,69 \times 10^{6} \pm 0,35$ & $15,86 \pm 0,748$ & $42,00 \pm 2,00$ \\
\hline
\end{tabular}

TABLE II - Biochemical parameters of serum of rats treated or not with $500 \mathrm{mg} / \mathrm{kg}$ body wieght of Pothomorphe umbellata crude ethanolic dried extract by gavage during 40 days, 5 days per week

\begin{tabular}{|c|c|c|c|c|c|c|c|c|}
\hline Group & $\begin{array}{c}T \text { P } \\
(\mathrm{g} / \mathrm{dl})\end{array}$ & $\begin{array}{l}\text { Glucose } \\
(\mathrm{mg} / \mathrm{dl})\end{array}$ & $\begin{array}{c}\text { Cholesterol } \\
(\mathrm{mg} / \mathrm{dl})\end{array}$ & $\begin{array}{c}\text { Tryglycerides } \\
\text { (mg/dl) }\end{array}$ & $\begin{array}{c}\text { Urea } \\
(\mathrm{mg} / \mathrm{dl})\end{array}$ & $\begin{array}{c}\text { Creatinine } \\
\text { (mg/dl) }\end{array}$ & $\begin{array}{c}\text { ALT } \\
\text { (UI/L) }\end{array}$ & $\begin{array}{c}\text { AST } \\
\text { (UI/L) }\end{array}$ \\
\hline \multicolumn{9}{|l|}{ Male } \\
\hline Control & $6.64 \pm 0.15$ & $116.8 \pm 15.96$ & $80.7 \pm 12$ & $50.1 \pm 8.50$ & $59.1 \pm 4.93$ & $0.75 \pm 0.08$ & $49.7 \pm 6.77$ & $37.6 \pm 7.87$ \\
\hline Treated & $6.25 \pm 0.40^{*}$ & $124.9 \pm 21.69$ & $77.5 \pm 10.61$ & $69.7 \pm 16.17 *$ & $57.6 \pm 8.29$ & $0.71 \pm 0.05$ & $56.2 \pm 9.60$ & $42.5 \pm 13.76$ \\
\hline \multicolumn{9}{|l|}{ Female } \\
\hline Control & $6.27 \pm 0.50$ & $136.5 \pm 40.86$ & $70.8 \pm 16.86$ & $76.7 \pm 27.91$ & $49.5 \pm 7.63$ & $0.69 \pm 0.08$ & $62.1 \pm 13.00$ & $34.7 \pm 8.9$ \\
\hline Treated & $5.74 \pm 0.85^{*}$ & $107.9 \pm 30.47$ & $66.7 \pm 5.92$ & $77.7 \pm 17.31$ & $44.5 \pm 7.11$ & $0.7 \pm 0.09$ & $47 \pm 8.46^{*}$ & $37.3 \pm 12.23$ \\
\hline
\end{tabular}

ALT - alanine amino transferase, AST - aspartate amino transferase, T P - total proteins; * Significant, P $\leq 0.05$ 
TABLE III - Relative and absolutive frequency of micronuclei in bone marrow cells of mice treated or not with Pothomorphe umbellata crude ethanolic dried extract by gavage

\begin{tabular}{lcc}
\hline GROUP $^{a}$ & ABSENCE (\%)/A & PRESENCE (\%)/A \\
\hline Cyclophosphamide (PC) 50 mg/kg & $96,98 / 14548$ & $3.01^{* / 452^{*}}$ \\
Distillated water (NC) & $99,96 / 14995$ & $0.03 / 5$ \\
Extract $1 \mathrm{~g} / \mathrm{kg}$ & $99,96 / 14994$ & $04^{* * / 6^{* *}}$ \\
Extract $2 \mathrm{~g} / \mathrm{kg}$ & $99,95 / 14992$ & $0.05^{* * / 8^{* *}}$ \\
Extract $5 \mathrm{~g} / \mathrm{kg}$ & $99,93 / 14992$ & $0.07^{* *} / 11^{* *}$ \\
\hline
\end{tabular}

* significant when compared with the distillated water treted group - $\mathrm{P} \leq 0.05$

$* *$ significant when compared with cyclophosphamide treated group $-\mathrm{P} \leq 0.05$

$\mathrm{PC}$ - positive control; NC - negative control

rules for studies of the toxicity of these products.

A great number of phytomedicines frequently employed in the therapeutic practice are obtained by ethanolic percolation. In the present work, the dried ethanolic root extract of Pothomorphe umbellata L. Miq was used seeking to reproduce the pharmaceutical preparation mentioned in Brazilian Pharmacopoeia (Silva, 1929) and assure total removing of the alcohol, substance that could interfere in the evaluation of the toxicity (Scivoletto \& Malbergier, 1996).

In this work we evaluated the oral acute toxicity of the dried ethanolic root extract of Pothomorphe umbellata L. Miq. employing the Limit Dose test that allows evaluating the lethality potential and the possible toxicant effects developed in a short period of time (United States, 1992).

Acute toxicity study indicated that water suspension of Pothomorphe umbellata L. Miq. crude ethanolic extract is not toxic when administered by the oral route to experimental animals. Similar results were described by Bacchi et al. (1995), in a study with hydroalcoholic extracts of Styrax camporum and Caesalpinia ferrea, and Nyarko et al. (1999), with the aqueous extract of Indigofera arrecta. Our results were comparable with these ones, due to the likeness in the classification of the phenolic compounds (in agreement with the basic skeleton - C6 - radical) (Carvalho et al., 1999) present in the extracts, to the form and to the administration period.

To the likeness of the acute study, the results of weight variations and consumption of water and food after repeated doses (subchronic treatment) did not present also any significant alterations after subchronic treatment.

Regarding serum biochemical parameters, a decrease of $6 \%$ and $8 \%$ was observed in total protein concentration in males and females, respectively. Tryglycerides were increased by $39 \%$ in males relatively to the control group. AST activity were decreased by $24 \%$ only in females. In spite of these significant variations, the mean values were in the normal range described for the animal species employed in the study (Lang, 1993).

Hematological parameters of treated rats were not different from the controls and are also within the values described in the literature for this animal specie (Andrew, 1965; Archer et al., 1977; Birgel Junior et al., 1986; Jain et al., 1986; Jain, 1993).

Macro and microscopic examinations of the selected organs did not reveal abnormalities that could be ascribed to Pothomorphe umbellata L. Miq. administration.

The ethanolic dried root extract of Pothomorphe umbellata L. Miq. employed in the experiments presented approximately $6.5 \%$ of 4 -nerolidilcatecol, a phenolic compounds with high antioxidant activity (Barros et al., 1996). Considering that phenolic compounds, like BHT and BHA, can present mutagenic or carcinogenic properties (Williams et al., 1999; Botterweck et al., 2000; Chung et al., 2000), it was accomplished in this work the evaluation of the mutagenicity by the micronucleus test. This test approaches the real situation of therapeutics considering that it is an in vivo test. In many cases, positive in vitro mutagenicity tests are not obligatorily positive in vivo, because substances with mutagenic activity present in the extract can be not absorbed, minimizing, in this way, its mutagenic potential.

It is the case of the Tinnevelly senna (Senna), plant usually used as laxative, whose dry aqueous extract of beans or leaves presents positive results in the in vitro Ames test and in the Chinese hamster ovary cells $(\mathrm{CHO})$ assay. Mengs et al. (1999) evaluated the genotoxic activity of the aqueous extract of this plant in a genotoxicity in vivo assay using the bone marrow micronucleus test and obtained negative results. The positive in vitro results of extract of Tinnevelly senna are probably related to the presence of the aloemodin and emodin anthraquinones that produced mutagenic effects in several assays in vitro. 
However, these compounds did not present results in the assays in vivo. Considering that the concentrations for aloemodin and emodin in the plasma are distinctly lower $(<0.065 \mu \mathrm{g} / \mathrm{mL})$ in relation to an elevated dose of the extract of Tinnevelly senna $(2000 \mathrm{mg} / \mathrm{kg})$ and that the values of these substances in the human plasma in therapeutics conditions are inferior to $0.2 \mathrm{ng} / \mathrm{mL}$, the authors concluded there not to be a genotoxic risk for the therapeutic use of the Senna as laxative, and that the in vitro results were overestimated.

The literature is absent in relationship to the toxicity evaluation of extracts of Pothomorphe umbellata L. Miq., as well as of its components. Only Mongelli et al. (1999) reported the citotoxicity of 4-nerolidylcatechol demonstrating that, by a mechanism of inhibition of the activity of topoimerase I, this substance induces growth inhibition of KB cells.

The results of the micronucleus test presented in this work corroborate the study of Felzenszwalb et al. (1987) that described the absence of mutagenicity of the dried ethanolic root extract of Pothomorphe umbellata L. Miq., when the Ames test was employed.

Putting together, the results presented in this paper conclude for the absence of oral toxicity of the dried ethanolic root extract of Pothomorphe umbellata L. Miq. after water suspension administration to laboratory animals.

\section{CONCLUSIONS}

A single oral dose of 1,2 and $5 \mathrm{~g} / \mathrm{kg} \mathrm{w}$. b. of dried ethanolic root extract of Pothomorphe umbellata L. Miq. ("Limit test), was unable to induce mortality or toxic effects in rats and mice. Similarly, subchronic toxicity test in rats, dosed $500 \mathrm{mg} / \mathrm{kg}, 5$ days per week during 40 days demonstrated that the extract is innocuous. The bone marrow micronucleus test showed no mutagenic activity at the doses of 1,2 and $5 \mathrm{~g} / \mathrm{kg}$. In summary, the data on the acute and subchronic studies indicate the low toxicity and the absence of mutagenic activity of Pothomorphe umbellata L.Miq crude dried ethanolic extract.

\section{ACKNOWLEDGMENTS}

The authors thanks the Fundação de Amparo a Pesquisa do Estado de São Paulo- FAPESP- for the fellowship for Sonia Barros Master degree Program at the Programa de Pós-Graduação em Análises Toxicológicas, Faculdade de Ciências Farmacêuticas, Universidade de São Paulo.

\section{RESUMO}

\section{Avaliação da toxidade oral aguda e subcrônica de extrato etanólico de Pothomorphe umbellata L. Miq. (Parapiroba)}

Existe uma grande preocupação quanto ao uso seguro de extratos vegetais e, por esta razão, a necessidade de estudos toxicológicos pré-clínicos e clínicos destes extratos. O objetivo deste trabalho foi o de avaliar a toxicidade aguda e subcrônica do extrato hidroalcoólico liofilizado de Pothomorphe umbellata L. Miq., administrado por via oral para animais de laboratório. O potencial mutagênico do extrato foi também avaliado pelo teste do micronúcleo. Os resultados dos estudos a curto e médio prazo demonstraram que o extrato não apresenta propriedades tóxicas.

UNITERMOS: Pothomorphe umbellata L. Miq.. Avaliação da toxicidade oral aguda. Avaliação da toxicidade oral subcrônica. Avaliação mutagênica.

\section{REFERENCES}

ANDREW, W. Comparative hematology. New York: Grune \& Stratton, 1965. p.144-146.

ARCHER, R. K.; JEFFCOTT, L. B.; LEHMANN, H. Comparative clinical haematology, Oxford: Blackwell, 1977. p.611-613.

BACCHI, E. M. Controle de qualidade de fitoterápicos. In: Di STASI, L.C., (Org). Plantas medicinais: arte e ciência. São Paulo: Ed. UNESP, 1996. p.169-186.

BACCHI, E. M.; SERTIÉ, J. A.; VILLA, N.; KATZ, H. Antiulcer action and toxicity of Styrax camporum and Caesalpinia férrea. Planta Med., Stuttgart, v.61, p.204207, 1995.

BARROS, S. B. M.; TEIXEIRA, D. S.; AZNAR, A. E.; MOREIRA JUNIOR, J. A.; ISHII, I.; FREITAS, P. C. D. Antioxidant activity of ethanolic extracts of Pothomorphe umbellata L. Miq. (Pariparoba). Ciênc. Cult., São Paulo, v.48, n.1/2, p.114-116, 1996. 
BIRGEL JUNIOR, E. H.; BENESI, F. J.; LENZ, F. F.; BIRGEL, E. H. Estudo das variações de parâmetros hematológicos de animais de laboratório I hemograma de ratos (Rattus novergicus). In: CONFERÊNCIA ANUAL DA SOCIEDADE PAULISTA DE MEDICINA VETERINÁRIA. 41., São Paulo, 1986. Resumos. São Paulo: Sociedade Paulista de Medicina Veterinária, 1986. p.1-3.

BOTTERWECK, A. A. M.; VERHAGEN, H.; GOLDBOHM, R. A.; KLEINJANS J.; VAN DEN BRANDT, P. A. Intake of butilated hydroxyanisole and butilated hydroxytoluene and stomach cancer risk: results from analyses in the Netherlands cohort study. Food Chem. Toxicol., Oxford, v.38, p.599-605, 2000.

BRASIL. Ministério da Saúde. Agência Nacional de Vigilância Sanitária. Resolução RDC n ${ }^{\circ} 17$ de 24 fev. 2000. Dispõe sobre o registro de medicamentos fitoterápicos, Diário Oficial da União, Brasília, 25 fev. 2000. Disponível em: <http://www.anvisa.gov.br/resol/ 2000/17_00rdc.htm/>. Acesso em: 04 abr. 2002.

BRASIL. Ministério da Saúde. Agência Nacional de Vigilância Sanitária. Resolução n 196 de 10 out. 1996. Conselho Nacional de Saúde, 1996. Disponível em: <http:/ /www.anvisa.gov.br/legis/resol/196_96.htm/>. Acesso em: 04 abr. 2002.

BRITO, A. R. M. S. Toxicidade aguda (dose simples e doses repetidas), subcrônica e crônica. In: BRITO, A.R.M.S. Manual de ensaios toxicológicos in vivo. Campinas: Ed. UNICAMP; Rio de Janeiro: Ed. Três, 1994. p.15-50.

CALLE, A. J. Contribucion al estudio de algunas espécies de la familia Piperaceae. Rev. Colomb. Cienc. Quim. Farm., Bogotá, v.4, p.47-57, 1983.

CARVALHO, J. C. T.; GOSMANN, G.; SCHENKEL, E. P. Compostos fenólicos simples e heterosídicos. In: SIMÕES, C. M. O.; SCHENKEL, E. P.; GOSMANN, G.; MELLO, J. C. P. de; MENTZ, L. A.; PETROVICK, P. R., (Orgs.). Farmacognosia da planta ao medicamento. Porto Alegre; Florianópolis: Ed. UFRGS; Ed.UFSC, 1999. p.433-449.

CHUNG, J. G.; YEH, C. C.; WU, H. C.; LI, Y. C.; LEE, Y. M.; HUNG, C. F. Effects of butylated hydroxyanisole and butylated hydroxytoluene on DNA adduct formation and arylamines $\mathrm{N}$-acetyltransferase activity in PC-3 cells (human prostate tumor) in vitro. Food Chem. Toxicol., Oxford, v.38, p.977-983, 2000.
COLÉGIO BRASILEIRO DE EXPERIMENTAÇÃO ANIMAL (COBEA). Legislação e Ética.Resolução N ${ }^{\circ}$ 592. Disponível em: <http://www.meusite.com.br/ COBEA/>. Acesso em: 01 ago. 2003.

FELZENSZWALB, I.; VALSA, J. O.;ARAÚJO, A. C.; ALCÂNTARA-GOMES, R. Absence of mutagenicity of Pothomorphe umbellata and Pothomorphe peltata in the Salmonella/mammalian microsome mutagenicity assay. Braz. J. Med. Biol. Res., Ribeirão Preto, v.20, p.403-405, 1987.

GIBBS, R.D. Chemotaxonomy of flowering plants. Quebec: McGill Queens Univerity Press, 1974. p. 15321537.

GORNALL, A. G.; BARDAWILL, C. J.; DAVID, M. M. Determination of serum proteins by means of the biuret reactions. J.Biol.Chem., Baltimore, v.177, p.751-766, 1949.

HENRY, J. B. Clinical diagnosis and management by laboratory methods 18.ed. New York: W.B. Sanders Company, 1991.p.141-142.

HODGSON, E. Toxicity testing and risk assessment. In: HODGSON, E.; LEVI, P. E. A textbook of modern toxicology. Connecticut: Appleton \& Lange, 1997. p.285338.

JAIN, N. C. Essentials of veterinary hematology. Philadelphia: Lea \& Febiger, 1993. p. 54-71.

JAIN, N. C.; SCHALM, O. W.; CARROLL, E. J. Veterinary hematology. Philadelphia: Lea \& Febiger, 1986. p.235-245.

KIJJOA, A.; GIESBRECHT, A. M.; AKISUE, M. K.; GOTTlieB, O. R.; GOTTLiEB, H. E. 4 nerolydilcatechol from Pothomorphe umbellata. Planta Med., Stuttgart, v.39, p.85-87, 1980.

KJELDSBERG, C. R. Princípios do exame hematológico. In: LEE, G. R.; BITHELL, T. C.; FOERSTER, J.; ATHENS, J. W.; LUKENS, J. N., (Eds.). Wintrobe hematologia clínica. São Paulo: Manole, 1998. v.1, 7-42.

KRYSIAK, B.; RYDZYNSKI, K.; STETKIEWICZ, J.; STETKIEWICZ, I. A subchronic toxicity study of Rokanol B-2 in rats. Int. J. Occupat. Med. Environ. Health, v.9, n.4, p.351-364, 1996. 
LANG, P. L. Serum chemistry parameters for the Crl: $C D^{\circledR}$ BR rat. Philadelphia: Charles River Laboratories, 1993. p.1-26.

LARSEN, K. Creatinine assay by a reaction - kinetic principles. Clin. Chim. Acta, Amsterdam, v.41, p.209-217, 1972.

MADRIGAL-BUJAIDAR，E.; BARRIGA，S. D.; CASSANI, M.; MOLINA, D.; PONCE, G. In vivo and in vitro induction of sister cromatid exchanges by nordihydroguaiaretic. Mutat. Res., Amsterdam, v.412, p.139-144, 1998.

MENGS, U.; GRIMMINGER, W.; KRUMBIEGEL, G.; SCHULER, D.; SILBER, W.; VOLKNER, W. No clastogenic activity of a Senna extract in the mouse micronucleus assay. Mutat. Res., Amsterdam, v.444, p.421-426, 1999.

MENGS, U.; KRUMBIEGEL, G.; VÖLKNER, W. Lack of emodin genotoxicity in the mouse micronucleus assay. Mutat. Res., Amsterdam, v.393, p.289-293, 1997.

MONGELLI, E.; ROMANO, A.; DESMARCHELIER, C.; COUSSIO, J.; CICCIA, G. Cytotoxic 4-nerolidylcatechol from Pothomorphe peltata inhibits Topoisomerase I activity. Planta Med., Stuttgart, v.65, p.376-378, 1999.

MOURA, R. A. A. Técnicas de laboratório. 2.ed. Rio de Janeiro: Atheneu, 1982. p.39-41.

NYARKO, A. K.; ANKRAH, N.; OFUSUHENE, M.; SITTIE, A. A. Acute and subchronic evaluation of Indigofera arrecta: absence of both toxicity and modulation of selected cytochrome $\mathrm{P} 450$ isozymes in $\mathrm{ddY}$ mice. Phytother. Res., Chichester, v.13, p.686-688, 1999.

ORGANISATION DE COOPERATION ET DE DEVELOPPEMENT ECONOMIQUES (OCDE). Lignes directrices de $1^{\prime} \mathrm{OECD}$ pour lês essais de produits chimiques: effets sur la santé. (section 4-article 401). Paris: Difusión General, 1981.p.1-8.

ORGANIZATION FOR ECONOMIC COOPERATION AND DEVELOPMENT (OECD). OECD Guideline for testing of chemicals: revised draft guideline 420 . nov. 1999. p 1-11. Disponível em: <http://www.oecd.org/>. Acesso em: 01 mar. 2000.
PANIZZA, S. Plantas que curam: cheiro de mato. 15.ed. São Paulo: Ibrasa, 1997. p.159-160.

PEARSE, A.G.E. Histochemistry. London: Churchill, 1968. v.2,p.1-26.

PEREIRA, C. A. B. Teste estatístico para comparar proproções em problemas de citogenética. In: RABELLO-GAY, M. N.; RODRÍGUEZ, M. A. L. R.; MONTELEONE-NETO, R. (Eds.). Mutagênese, carcinogênese e teratogênese: métodos e critérios de avaliação. Ribeirão Preto: Sociedade Brasileira de Genética, 1991.p.113-121.

RABELLO-GAY, M.N. Teste de micronúcleo em medula óssea. In: RABELLO-GAY, M. N.; RODRÍGUEZ, M. A. L. R.; MONTELEONE-NETO, R., eds. Mutagênese, carcinogênese e teratogênese: métodos e critérios de avaliação. Ribeirão Preto: Sociedade Brasileira de Genética, 1991. p.83-90.

RIBEIRO, L. R.; TAKAHASHI, C. S.; ERDTMAN, B.; OLIVEIRA, S. V.; COSTA, C. T. A.; GIMMELERLUZ, M. C. Inter-Laboratory Calibration Program for the mouse micronucleus test. Rev. Bras. Genet., Ribeirão Preto, v.16, n.3, p.631-638, 1993.

SCIVOLETTO, S.; MALBERGIER, A. Etanol. In: Oga, S. Fundamentos de toxicologia. São Paulo: Atheneu, 1996. p.283-296.

SILVA, R. A. D. Pharmacopeia dos Estados Unidos do Brasil. São Paulo: Ed. Nacional, 1929. p.444, 649 e 946.

SMITH, J. E. Comparative hematology . In: BEUTLER, E.; LICHTMAN, M. A.; COLLER, B. S.; KIPPS, T. J., (Eds.). Williams hematology. 5.ed. New York: McGrawHill, 1995. p.77-85.

UNITED STATES. Environmental Protection Agency. Code federal regulations. Title 40: Protection of environment. Health effects testing guidelines. Washington: U. S. Government Printing Office, 1992. p.433-465.

VAITTINEN S. L.; KOMULAINEN, H.; KOSMA, V. M.; JULKUNEN, A.; MÄKIPAAKKANEN, J.; JANSSON, K.; VARTAINEN, T.; TUOMISTO, J. Subchronic toxicity of 3 - chloro - 4- (dichloromethyl) 5 -hydroxy - 2 (5h) - furanone (MX) in wistar rats. Food Chem. Toxic., Kuopio, v.33, n.12, p.1027-1037, 1995. 
VAN DEN BERGH, M.E. Plantas medicinais da Amazônia: contribuição ao seu conhecimento sistemático. Belém: CNPq/PTU, 1993. p.59-61.

WALKER, A. P. The work of OECD in the harmonization of the testing and control of chemicals. Food Chem. Toxicol., Oxford, v.22, n.11, p.905-908, 1984.

WILLIAMS, G. M.; IATROPOULOS, M. J.; WHYSNER, J. Safety assessment of butilated hydroxyanisole and butilated hydroxytoluene as antioxidant food additives. Food Chem. Toxicol., Oxford, v.37, p.1027-1038, 1999.
WONG, W. S.; McLEAN, A. E. M. Effects of phenolic antioxidants and flavonoids on DNA synthesis in rat liver, spleen, and testis in vitro. Toxicology, Amsterdam, v.139, p.243-253, 1999.

WORLD HEALTH ORGANIZATION (WHO). Guide to short-term tests for detecting mutagenic and carcinogenic: chemicals. Geneva: WHO, 1985. p.100-115. (Environmental Health Criteria, n.51).

Recebido para publicação em 01 de setembro de 2003. Aceito para publicação em 02 de março de 2005. 